\title{
Intellectual Capital and Firm Performance in the Context of Venture-Capital Syndication Background in China
}

\author{
Yuzhong Lu (D), ${ }^{1}$ Zengrui Tian, ${ }^{1}$ Guillermo Andres Buitrago, ${ }^{1}$ Shuiwen Gao, \\ Yuanjun Zhao $\mathbb{D}^{2}$, and Shuai Zhang ${ }^{3}$ \\ ${ }^{1}$ The Glorious Sun School of Business and Management, Donghua University, Shanghai200050, China \\ ${ }^{2}$ School of Business Administration, Shanghai Lixin University of Accounting and Finance, Shanghai 201209, China \\ ${ }^{3}$ University of Greenwich, London SE10 9LS, UK
}

Correspondence should be addressed to Zengrui Tian; 1189197@mail.dhu.edu.cn

Received 15 July 2020; Revised 6 February 2021; Accepted 11 March 2021; Published 27 March 2021

Academic Editor: Thiago Christiano Silva

Copyright (c) 2021 Yuzhong Lu et al. This is an open access article distributed under the Creative Commons Attribution License, which permits unrestricted use, distribution, and reproduction in any medium, provided the original work is properly cited.

This paper is intended to investigate the role of Venture-Capital Syndication (VCS) background in the relationship between intellectual capital (IC) and portfolio firm performance (PFP); specifically, this article examines the moderating effect of VCS's leading firm background and member heterogeneity on the effect of IC on PFP. This study used a modified VAIC model to measure IC to compose a 4-component variable including human capital, structural capital, relational capital, and innovation capital. The data were collected from VCS-backed and listed firms in China during 2014 to 2018 applying the pooled OLS model for hypotheses test, Generalized Method of Moments (GMMs) to reduce endogeneity and unobserved factor control, and also return on equity (ROE) instead of ROA for the robustness test. Empirical results showed that IC and its components can improve PFP for VCS-backed firms in China; in detail, IC showed greater impact on performance of firms invested by foreign lead investors than in private or government VCS, specially reflected in the impact of innovation capital on PFP. Furthermore, IC showed weaker impact on PFP of mixed VCS-backed firms compared to pure VCS-backed firms and showed diminished effect on higher VCS member heterogeneity mainly reflected in the impact of relational capital on firm performance. These findings propose a new way of combining IC and VC to improve firm performance and are beneficial to theoretical development of IC and VC as well as a perspective for VC firm managers to choose suitable partners prior to join a VCS.

\section{Introduction}

In a knowledge-based economy, there have been growing consensus about the relevance of Intellectual Capital on firms long-term profit [1-3], even more, intangible assets are being identified as one of their core capabilities [4]. Intellectual capital (IC) is usually defined as the total of all knowledge that a firm can use as source of competitive advantage $[5,6]$. Empirical evidence has shown that intellectual capital can improve firm's competitive advantage [7-9], and it is also closely related to high-level firm performance $[2,8,10]$.

Being one of the most of the Asian emerging economies, China has experienced "high growth and high investment" for a long period after the reform and opening policy [11];
Chinese firms have consequently seen an accelerated growth on their own intellectual capital on the latest decades [12]; however, in comparison with developed countries in Europe and America, Chinese research on intellectual capital still needs further development [13]; although the gap between China and developed economies in terms hard power has been narrowed, the construction of soft power can be considered relatively backwards, even more, Chinese reserves in intellectual capital are still insufficient to follow the recent pace of development [14]. Even more, intellectual capital has been tagged by the government of China as a precious resource of a country, emphasizing its importance as a supporting force for the Chinese development strategy during this critical period of economic transformation and upgrade [14]. 
On intellectual capital, value-added intellectual coefficient (VAIC) is considered a standardized and logical measurement method [15]; it can use relevant data from financial reports to calculate firm value creation efficiency, enabling the possibility of making comparisons with other related firms [8]. In its original form, VAIC assessed IC only through human capital and structural capital [15]; nevertheless, further researchers refined this methodology to include neglected related components such as social capital, customer capital [16-18], and innovation capital [10, 19], innovation capital efficiency being a factor with direct impact on firms' performance [10, 20]; in China as well as other emerging economies, entrepreneurship and innovation are considered the new driving forces for economic growth; based on that importance, innovation capital is a component that needs to be included in the VAIC model to properly identify the impact of intellectual capital on firm performance.

Since capital is the foundation of firm development, knowledge and technology are sources for innovation; in terms of mass innovation, the effective combination of IC and venture capital not only can promote the integration of knowledge, technology, and capital within a firm but also present significance on improving firm performance $[3,19,21]$. Additionally, it is also conducive to innovation and sustainable development of emerging economies [22]. As a financing method to provide capital and service support to firms, venture capital (VC) has been rising for a long time in developed countries; it not only provides sufficient funding support for the portfolio firms but also provides other value-added services [23], such access to enhanced human capital as well as relational capital for firm's portfolio $[24,25]$ and technological performance [26]. With the notable economic growth of China, this country has seen the emergence of new entrepreneurial firms, while most of these firms have been facing financing constraints [27]; venture capital (VC) provides financing and rapid growth opportunities for some of them [23, 28, 29]. Since intellectual capital plays a key role in entrepreneurial firms [1, 2, 21, 30], it is necessary to investigate the impact of intellectual capital on performance for VC-backed firms' portfolio.

To share resources and risks, most venture capital institutions prefer joint investment [23, 31, 32]; more specifically, they rely on venture-capital syndication (VCS), where even different types of venture capital firms can share participation in entrepreneurships. According to the development background of Chinese VC Industry, capital types, and main funds of VC firms in the database of Zero2IPO Research Center [33], Chinese VC firms can be divided into three types: (1) foreign-funded venture capital (FVC); (2) domestic private venture capital (DPVC); and (3) government-funded venture capital (GVC) [34] as shown in Table 1.

Given its heterogeneity and complementarity, VCS can provide firms wider access to funding, resources, and extensive value-added services that promote faster firm development, overcoming the constraints of previous investment experience and geographical location $[31,35,36]$.The impact of different backgrounds of VCS on portfolio firms is different $[34,37]$, and the impact of intellectual capital of portfolio firms in performance may differ depending on VCS background. Therefore, it makes it necessary to research the role of VCS background between intellectual capital and firm performance.

Although considerable number of studies have addressed the activity of IC in emerging economies [38-40], previous research has been focused on IC measurement [41-44], IC impact on value creation $[8,9,20]$, and innovation [21, 41]; research on VCS effects is quite limited. (1) Does intellectual capital (including the four dimensions of human capital, structural capital, relational capital, and innovation capital) have a positive impact on portfolio firm performance? (2) Are these impacts varying with firms backed by FVC-led, DPVC-led, or GVC-led syndication? (3) What is the role of member background heterogeneity in the relationship of intellectual capital and firm performance? This study is oriented to address these questions within the framework of VCS background in China.

VC industry in China offers some advantages as a suitable setting to examine these issues: (1) With the rapid growth of China's venture capital industry in recent years, many VC firms have emerged, supporting also many small and medium-sized firms, providing an appropriate number of observable sample data for our research. (2) With the development of the Chinese market and the gradual dynamization of the economic system, an increasing number of FVC have entered to the Chinese market [45]. Their experience, management methods, and technologies have brought opportunities and challenges to Chinese firms. It is therefore helpful to empirically examine whether the impact of intellectual capital on firm performance vary depending on the VCS background.

For hypothesis testing, this empirical study used the modified Pulic's VAIC ${ }^{\mathrm{TM}}$ model to measure IC [41, 46], assessing it in terms of four components: (1) human capital, (2) structural capital, (3) relational capital, and (4) innovation capital. Our sample included 575 Chinese venturecapital syndication backed firms listed in the A-share market during 2014 to 2018. Our model expects that all components of IC may influence the performance of VCS-backed firms, moderated by the background of VCS. Additionally, this exercise also tested moderation by FVC-led, DPVC-led versus GVC-led syndication, as well as the moderating effect of cooperation model and member heterogeneity. Several methods were applied to address the empirical challenges of potential endogeneity: (1) first, the the pooled OLS model were used to test hypotheses; (2) second, the average value of IC of the sample firm's industry was used as its own instrumental variable [46, 47]; (3) third, the generalized method of moments (GMMs) was used to reduce endogeneity problems and control unobservable factors; and (4) finally, return on equity instead of ROA was used to test the models' robustness of the obtained results.

The contributions of this study are presented in three ways: (1) first, this study contributes to the literature on the relation between intellectual capital (IC) and portfolio firm performance (PFP), by filling the gap of empirical research on the relationship among IC, background of VCS, and firm 
TABLE 1: Classification of Chinese venture capital firms.

\begin{tabular}{|c|c|c|c|}
\hline Type & Main source of funds & $\begin{array}{l}\text { Representative VC } \\
\text { institutions }\end{array}$ & Investment target \\
\hline $\begin{array}{l}\text { Government venture } \\
\text { capital (GVC) }\end{array}$ & $\begin{array}{l}\text { Provided by local government, state- } \\
\text { owned firms, government-affiliated } \\
\text { institutions, and universities }\end{array}$ & $\begin{array}{l}\text { (i) China Venture } \\
\text { Capital } \\
\text { (ii) Shanghai STVC } \\
\text { Group } \\
\text { (iii) Shenzhen Capital } \\
\text { Group } \\
\text { (iv) Wuhan Huagong } \\
\text { Venture Capital, etc. }\end{array}$ & $\begin{array}{l}\text { (i) Realize government policy goals } \\
\text { (ii) Support entrepreneurial firms } \\
\text { (iii) Cultivate small- and medium-sized } \\
\text { technology firms } \\
\text { (iv) Guide social capital investment }\end{array}$ \\
\hline $\begin{array}{l}\text { Domestic private } \\
\text { venture capital } \\
\text { (DPVC) }\end{array}$ & $\begin{array}{l}\text { All provided by Chinese private firms and } \\
\text { domestic wealthy individuals }\end{array}$ & $\begin{array}{l}\text { (i) Fortune Capital } \\
\text { (ii) Cowin Capital } \\
\text { (iii) Detong Capital } \\
\text { (iv) JD Capital, etc. }\end{array}$ & $\begin{array}{l}\text { As a strategic tool for firms, seek new value- } \\
\text { added opportunities to realize value } \\
\text { creation and capital growth }\end{array}$ \\
\hline $\begin{array}{l}\text { Foreign venture } \\
\text { capital (FVC) }\end{array}$ & $\begin{array}{l}\text { Provided by foreign capital (such as } \\
\text { foreign investment banks, foreign firms, } \\
\text { and foreign wealthy individuals) }\end{array}$ & $\begin{array}{l}\text { (i) IDG Capital } \\
\text { (ii) SEQUOIA China } \\
\text { (iii) Matrix Partners } \\
\text { China } \\
\text { (iv) NewMargin, etc. }\end{array}$ & $\begin{array}{l}\text { (i) Use its rich management experience, } \\
\text { professional skills, and financial advantages } \\
\text { (ii) Value-added appreciation and profit }\end{array}$ \\
\hline
\end{tabular}

performance. Our main results are consistent with the view that human capital, structure capital, and relational capital have positive impact on PFP $[30,48,49]$, and innovation capital also has positive association with PFP [10]. In addition, we gave special focus on the moderating effects of venture-capital syndication background. We argue that a positive influence of IC on portfolio firm performance is significantly higher in the context of FVC-led syndication than in DPVC-led or GVC-led syndication. Therefore, in emerging economies, especially the case of China, DPVCs and GVCs would need to learn from the advanced investment management experience and skills of FVCs in line with the local environment, to increase the efficiency of firm intellectual capital.

(2) Second, this study adds both academic and practical value to the field of venture capital and portfolio firms. Our results supported the view of $[34,50]$, where VC firms are more inclined to cooperate with other VC firms that have smaller differences with themselves. We argue that the positive influence of IC on portfolio PFP in pure VCS is significantly higher than that in mixed VCS, suggesting that when considering financing, portfolio firms may prefer pure VCS, more conducive to value creation of intellectual capital and the improvement of portfolio firm performance. Moreover, the particularity of this research setting provides a fresh perspective on intellectual capital management of portfolio firm for performance as well as relevant implications for portfolio firms in emerging countries.

\section{Literature Review and Hypothesis Development}

2.1. Intellectual Capital and Its Components. Intellectual capital (IC) was first proposed by Galbraith in 1969, who defined it as an intellectual activity that contribute to a dynamic kind of capital. Stewart [16] defined it as knowledge, intellectual property, information, and experience that can bring competitive advantage and created value for a firm; Sullivan and Patrick [51] considered it as knowledge and information that can be converted into a tangible profit for a firm. Although further consensus is needed, in [16], definition has been widely adopted, considering that IC includes human capital, structure capital, and relational capital $[2,16,52]$. Human capital is mainly reflected in knowledge, skills, culture, and other of employee-related aspects [53, 54]; Structural capital refers to intangible assets such as firm organizational structure, rules, and strategies $[55,56]$, It is considered relevant on improving business operations efficiency and promoting the maximum value of human capital $[57,58]$. Relational capital mainly refers to the value created by stakeholders such as partners, suppliers, and customers [59-61] and can effectively help firms to deal with internal and external relationships reflected mainly in employees, customers, and strategic partners loyalty [48, 62].

As an intangible asset, an objective measure for intellectual capital may be difficult to develop; however, Pulic [15] through his value added intellectual coefficient model (VAIC) addressed this measurement through human capital and structure capital, based in a firm's financial data. Since the VAIC model can clearly reflect value creation efficiency of a firm intangible and tangible assets, it made possible to perform comparisons between organizations and have been extensively adopted in research [62-64]. Nevertheless, further research identified relevant components of intellectual capital that were previously ignored, such as in the case of [65] who identified 4 components: human capital, structural capital, innovation capital, and customer capital, proving the validity and rationality of the modified VAIC model; following the line, [66] introduced customer capital and process capital to the extended VAIC model; Chen et al. [41] 
expanded the model including internal and external dimensions, both with its respective human capital, structure capital, and relationship capital. Even in recent years, the VAIC model has evolved giving space to innovation capital into the model $[7,10]$.

In emerging economies, innovation capital plays an important role in firm development. Previous research defined it as the intangible assets or capabilities that can promote innovation in knowledge, service, technology, and other aspects of the firm $[7,41]$ and regard it as the product of the firm's human capital, social capital, and reputational capital [41, 67]. It is conducted to the creation of knowledge and the increase of intellectual property $[10,68]$. Since the VAIC model does not include innovation capital and its main components include firm's labor, physical capital [69], it designates the efficiency of the labor and capital investment rather than IC [70]. So, in this exercise, researchers modified the VAIC model by defining IC as composed by (1) human capital, (2) structural capital, (3) relational capital, and (4) innovation capital. The calculation of the modified VAIC model can be seen in variable definition and measurement chapter.

2.2. Venture Capital Syndication in China. Venture-capital syndication (VCS) is a common strategy in China; it enables VC firms to choose partners to share resources of capital, human talents, and scientific and technologic knowledge and also distribute venture associated risks [23]. It helps them to overcome boundaries of original investment industry and geographical limitations, being able to obtain information from distant sources, expanding the scope of their investment [36]. Existing literature suggests that VCS has a positive effect on entrepreneurial firms. Hochberg et al. [71] found that firms funded by from two or more VC firms are more likely to successfully exit through an IPO or being sold to another firm. Lu et al. [72] found stronger innovation capabilities in VCS-backed firms in comparison with individual VC-backed firms. Ren [73] pointed out that VCS not only can effectively make up for the human and material resources needed during further development of enterprises but also stimulate innovation capital and structural capital through human capital and constantly strengthen the original relationship capital of firms, effectively enhancing the value of portfolio firms.

According to the background of its members, VCS can be divided into two cooperation modes: "Pure" and "Mixed" [34]. Pure VCS mainly refers to the cooperation of the same type of VC firm, such as GVC with GVC and DPVC with other DPVC. Mixed VCS mainly refers to the cooperation between two or more types of VC firm. Giot and Schwienbacher [74] suggested that, for larger number of VC firms participating in a round of syndication, the larger will be the scale of investment, and the period from investment to successful realization of IPO exit will be reduced. Some literature points out that "mixed" VCS present significantly lower performance than that of "pure" VCS [34]. Different types of VC firms will face differences in resources, experience, and capabilities for management and monitoring, geographic locations, and even industry; their competitive advantages may be different [75]; it means that the valueadded service provided for the portfolio will be different, making in some cases the difference an obstacle to articulation between firms; in other words, the effect of intellectual capital on portfolio firm's performance may be likely affected by the VCS background.

Previous research suggested that venture capital firms with higher shareholding ratio and better reputation can improve firm efficiency through material capital and human capital [46]; in the same line, there is evidence where GVC increased firm efficiency through material capital and structural capital [76]. For VC firms with shareholding ratio higher than a certain threshold, IC may accelerate the improvement of asset utilization efficiency and market value [77]. Since VC firms in syndication have different types -and reputation-, VCS with different backgrounds may present different effect for each IC elements to improve firm efficiency. Therefore, research on how differences on VCS background may have influenced the effect of intellectual capital on portfolio firm performance acquires relevance.

Despite the existence of previous research on performance of mixed syndication involving GVC and DPVC in China [75], there is still a gap on explaining the influence of venture capital syndication (VCS) type on the relationship between intellectual capital (IC) and firm portfolio performance (FPF). Therefore, in the context of the Chinese venture capital market, this empirical exercise considers the type of syndicate leaders and the cooperation model of its members, specifically investigating the moderating effect of VCS in the previously mentioned relationship.

\subsection{Intellectual Capital and Portfolio Firm Performance.} As knowledge economy grows in relevance, previous studies have explored the impact of IC on PFP; as an instance, Bontis [62] showed that three components elements of IC, (1) human capital, (2) structural capital, and (3) customer capital, have positive relationship with PFP in a Malaysian sample. In [78], using a sample of US multinational firms, they found that IC may significantly improve return rate on total assets. In [79], the Indian software industry was used as context to find that a 2-component IC (human capital and structural capital) had positive impact on firm profitability. For the case of Pakistan, Waseem [13] showed significant positive effect of three IC components (human, relational, and technological) on organizational performance of large textile companies in Pakistan.

For the Chinese context, in [80], by using data from listed firms in computer industry, they found that 3-component IC (human, physical, and structural) showed positive contribution to PFP. In [81], it is confirmed that their 4component IC (human, innovation, process, and customer) presented positive impact on enterprise value creation for the Chinese pharmaceutical manufacturing industry. Xu and Wang [82] used VAIC ${ }^{\mathrm{TM}}$ and Modified VAIC ${ }^{\mathrm{TM}}$ model to analyze performance of IC in China and South Korea finding that human, relational, and structural capitals are all positively related to the profitability of textile firms. 
Compared to the non-VCS-backed ones, VCS-backed firms are more likely to have higher values on fostering intellectual capital; this may be because various reasons: (1) first, given the reserved character the information in portfolio companies, observers can judge firm quality by referring the behavior of any third party with information advantage [83]; therefore, the availability of information for a VCS partner provides clearer insights on the operation of the portfolio company [23]. Thus, external investors and job seekers regard VCS-backed firms to be more trustworthy, making these firms more likely to attract better human talents and financial support, explaining enhancements in firm performance $[31,84]$. (2) Second, VCS often has rich network resources, being able to provide head hunters, patent lawyers, investment bankers, or any other required talents that add value and contribute to portfolio firms [71]; it can also enhance relationships with partners, suppliers, customers, and government. [23,35]. (3) Third, VCS can provide value-added services such as management, technology, consulting, and others to portfolio firms [23], increasing the utilization rate of existing IC and the subsequent firm innovation performance [72]; consequently, IC of VCS-backed firms will tend to have better market performance. Based on the previous literature, it is possible to define the first hypothesis for this empirical exercise.

H1: 4-component intellectual capital (human capital, structural capital, relational capital, and innovation capital) has significant positive impact on VCS' portfolio firm performance.

2.4. Influence of VCS Leadership Heterogeneity. Leading VC Firm plays a key role in VCS, especially in screening, structuring, and monitoring portfolio firms [85], as the primary decision makers lead VC firms normally exercises a disproportionate influence over various VCS processes [75], therefore having privileged influence in the creation of IC within VCS portfolio firms; therefore, each VC firm definition as leading or nonleading as well as his nature (FVC, DPVC, or GVC) need to be accounted in terms of influence over IC within portfolio VC firms.

It is different that FVCs, DPVC, and GVC faced a late development in China with certain lack on investment and management experiences [86]. In GVC-led syndication, GVCs have the responsibility of stimulating local economic development [87]. In consequence, supervision and valueadded services provided in their portfolio firms may be different in comparison with DPVC-led or FVC-led. Analogically, there will be difference on the IC provided by portfolio firms. Previous research showed that most GVC lack on relevant professional knowledge and investment experience [88]. Other studies documented GVC underperformance, for example, Alperovych et al. [89] found that GVCs have poorer results on portfolio firms productivity when compared to DPVC; additional research showed similar results on human capital recruitment [90], sales growth [91], and innovation [88]. Thus, firms backed by GVC-led syndication will face lesser effectivity on IC and value creation.
On regard to FVC-led syndication, their partners are often invited to provide a second opinion on managing or diversifying value-added activities. In the Chinese case, most FVC comes from foreign professional investment banks, investment institutions, insurance institutions, and wealthy individuals from developed countries; compared with DPVCs or GVCs in China, FVCs have more resources in terms of social network, investment experience, management, and risk control [92], thus, FVCs may increase its IC through portfolio value-added services that can enhance firm value creation in higher proportion than GVC or DPVC in China [34]. Based on this, the next hypothesis can be constructed:

H2: compared DPVC-led or GVC-led syndication, intellectual capital shows more effectiveness in portfolio firm performance within FVC-led syndication.

2.5. Moderating Effect of VCS Members. VCS is composed of various VC firms that contribute with different funding sources, experience, talents, etc. Therefore, value-added services provided by each VCS portfolio firms have its own particularities, such as their IC and its ability to create value. The composition of VCS' members may influence the impact of IC on PFP. This exercise studied the role of VCS members in the relationship between IC and firm performance by studying the cooperation mode of VCS members and their heterogeneity.

Different from pure syndication, mixed syndication presents stronger member heterogeneity; in terms of resource-based theory, VCS with higher member heterogeneity implies higher diversity of resources, such as social relations, information access, and competitive advantages $[93,94][31,85]$; this model based in complementary cooperation provides also advantages in terms of value-added services such as knowledge, technology, and network relations among others [29] helpful for invested firms management of and post investment supervision. For example, FVCs have advantage on helping firms to establish professional governance structure and operating model [34]. By forming a heterogeneous syndicate with other DPVC or GVC in China, they will gain better understanding of local firms and their culture [95], increasing portfolio firm information resources and relationship capital, at the end improving their firm performance [96]. Lu et al. [72] found also that VCS with high member heterogeneity is more likely to be familiar with various stages of firm development, helping firms to use specialized operating models to improve innovation efficiency and develop IC. Therefore, the third hypothesis is built as follows.

H3a: stronger VC syndication member heterogeneity can increase the positive impact of investee's intellectual capital on portfolio firm performance.

However, human behavior may bring over a downside on VCS portfolio firms related to value creation within IC. Following the Social Classification Theory and Social Identity Theory, similar attitudes and values within a team will make individuals to identify with each other, classify team members, develop crowd preferences, and outgroup 
biases, further making team heterogeneity a factor for member conflicts, impacting negatively the group decision process [97, 98], and moving people away from teamwork [99]. In the case of VCS, member background diversity means greater heterogeneity in terms of values, corporate culture, management models, and investment concepts; however, wider environment is developed for bias development against VC firms with different background, facilitating the appearance of potential conflicts [84].

In terms of portfolio firm management, stronger member heterogeneity within VCS may extend the time for firm's decision-making [32], increasing management costs [50] as well as its portfolio trade sale hazard [100]. The occurrence of this situation harms the ability of the portfolio firms to make full use of the extended resources provided by the VCS, intended to enhance the value creation ability of intellectual capital. In other words, common member background in pure syndication allows smoother in communication and coordination $[34,75]$ provides more efficient services having also better positive effect on firm performance than the mixed syndication. Given these findings, a complementary hypothesis has been developed as follows.

H3b: stronger VC syndication member heterogeneity can reduce the positive impact of investee's intellectual capital on portfolio firm performance.

\section{Methodology}

3.1. Sample Collection. This empirical study used data from firms that accepted VCS funding and got successfully listed on Shenzhen and Shanghai stock exchanges during 2014 to 2018. The sample data were composed by two components: (1) VC data, obtaining the sample firms from [33] research database and the CV source database [101]. This dataset included VC firm names, their participation in VCS, firm background information, investment amount, and number of shares. (2) Relevant financial data of the sample firms were obtained from wind financial database [102], widely recognized in China for financial data. After deleting missing data and using tailing treatment at 5\%-99\% level, also eliminating the impact of extreme data, an overall number of 575 valid observations were obtained.

\subsection{Variable Definition and Measurement}

3.2.1. Dependent Variables. To measure portfolio firm performance, this study used return on assets (ROA) consistent with the previous literature $[2,7,10,19]$. It is a widely used indicator on firm profitability and is usually used to measure the efficiency of a firm. A higher ROA represents higher effectiveness of a firm's asset utilization.

For robustness check, this study used return on equity (ROE) as a proxy for firms' performance $[10,82]$.

3.2.2. Independent Variables. Based on the analysis presented in Section 2.1 of this article, this study measured intellectual capital by using the modified Pulic's VAIC ${ }^{\mathrm{TM}}$ model, measurement of IC, and its constituent elements as shown in Table 2.

3.2.3. Control Variables. Consistent with previous studies $[72,103,104]$, this empirical exercise included a set of 5 control variables as follows: (1) firm size, (2) debt ratio, (3) permanent asset ratio, (4) board size, and (5) total asset turnover ratio. The method of calculation for each variable is described in Table 2.

3.3. Empirical Models. According to the sample for this study, we assume that there is no individual effect. As the $p$ value of the $F$ test was 0.356 on the statistical assessment, the null hypothesis on individual effect could not be rejected. Therefore, a pooled OLS model was applied; to eliminate the heteroscedasticity and sequence-related problems and OLS + clustering robust standard error were chosen for regression.

3.3.1. Model for Hypothesis (H1). The following model (1) describes the model to assess $\mathrm{H} 1$ :

$$
\begin{aligned}
\text { Perform }_{i, t}= & \alpha_{1}+\beta_{1} X_{i, t}+\beta_{2} \text { Size }_{i, t}+\beta_{3} \text { Debt }_{i, t} \\
& +\beta_{4} P P E_{i, t}+\beta_{5} B N_{i, t}+\beta_{6} T A T_{i, t}+\varepsilon_{i, t},
\end{aligned}
$$

where Perform represents performance, $i$ represents the firm, $t$ represents the year, and $X_{i, t}$ represents $V A I C_{i, t}, H C E_{i, t}$, $S C E_{i, t}, I C E_{i, t}$, and $R C E_{i, t}$, respectively.

3.3.2. Model for Hypothesis (H2). Regression analysis was ran based on the values on leading type by running it in three groups according to each case: Lea d_type $=1 ;$ Lea d_type $=2 ;$ Lea d d type $=3 ; \quad$ then, group regression coefficients were compared through SUEST command. If the regression coefficients were significantly different, then, heterogeneity was considered significant. To perform in-depth analysis, this study not only grouped regression between the dependent variable (DV) and IC but also grouped regression between the DV and the components of IC.

3.3.3. Model for Hypothesis (H3). To evaluate H3a and H3b, this study introduced two interaction terms: (1) IC and VCS member heterogeneity and (2) IC's elements and VCS member heterogeneity, to construct the model described in the following equation. Then, hierarchical regression test was performed. If the regression coefficient of the interaction term was significant, then significance of its moderating effect was also significant.

$$
\begin{aligned}
\text { Perform }_{i, t}= & \alpha_{0}+\beta_{1} X_{i, t}+\beta_{2} \text { VCtypeHeter }_{i, t} \\
& +\beta_{3} X_{i, t} * \text { VCtypeHeter }_{i, t}+\beta_{4} \text { Size } \\
& +\beta_{5} \text { Debt }_{i, t}+\beta_{6} \text { PPE }_{i, t}+\beta_{7} B N_{i, t} \\
& +\beta_{8} T A T_{i, t}+\varepsilon_{i, t},
\end{aligned}
$$


TABLE 2: Variable definitions and measurement.

\begin{tabular}{|c|c|c|c|}
\hline Type & Variable & Definition & Measurement \\
\hline $\begin{array}{l}\text { Dependent } \\
\text { DV }\end{array}$ & ROA & Return on assets & Net incomes/average total assets \\
\hline \multirow{5}{*}{$\begin{array}{l}\text { Independent } \\
\text { IV }\end{array}$} & HCE & $\begin{array}{l}\text { Human capital } \\
\text { efficiency }\end{array}$ & VA/employee expenses \\
\hline & SCE & $\begin{array}{c}\text { Structural capital } \\
\text { efficiency }\end{array}$ & VA/management expenses \\
\hline & ICE & $\begin{array}{c}\text { Innovation capital } \\
\text { efficiency }\end{array}$ & VA/R\&D expenses \\
\hline & $\mathrm{RCE}$ & $\begin{array}{c}\text { Relational capital } \\
\text { efficiency }\end{array}$ & VA/sales expenses \\
\hline & VAIC & $\begin{array}{c}\text { Intellectual capital } \\
\text { efficiency }\end{array}$ & $\mathrm{HCE}+\mathrm{SCE}+\mathrm{ICE}+\mathrm{RCE}$ \\
\hline Moderator & VctypeHeter & VCS heterogeneity & $\begin{array}{l}-\sum_{i} p_{i} \ln p_{i} \\
\text { where } p_{i} \text { is the proportion of } i \text {-type VC institutions in the total number } \\
\text { participants within a VCS) }\end{array}$ \\
\hline \multirow{5}{*}{ Control } & Scale & Enterprise size & Logarithm of total assets \\
\hline & Debt & Debt ratio & Total liabilities/total assets \\
\hline & PPE & Permanent asset ratio & Permanent assets/total assets \\
\hline & $\mathrm{BN}$ & Board num & Number of board directors \\
\hline & TAT & Total asset turnover & Operating income/average total assets \\
\hline
\end{tabular}

Note: $\mathrm{VA}$ is the value added of a firm; $\mathrm{VA}=$ net profit + depreciation expense + income tax + financial expenses + salary payable + welfare payable

where Perform represents performance, $i$ represents the firm, $t$ represents the year, VCtypeHeter ${ }_{i, t}$ represents heterogeneity, and $X_{i, t}$ represents $V A I C_{i, t}, H C E_{i, t}, S C E_{i, t}, I C E_{i, t}$ and $R C E_{i, t}$, respectively.

\section{Empirical Results and Analysis}

4.1. Descriptive Statistics. Descriptive statistical analysis was conducted based on the background of the VCS leading firm and VCS cooperation model as shown in Table 3.

Based on Table 3, it can be inferred that (1) from the perspective of IC components, independent of the type of supporting VCS, there is a value pattern, where ICE $>$ RCE $>$ SCE $>$ HCE, meaning that, in terms of firm value creation ability, IC contribution follows the following pattern: innovation capital $>$ relational capital $>$ structural capital$>$ human capital. (2) From the perspective of VCS leading type, the ROA of DPVC-led syndication backed firms is higher than that those of FVC-led or GVC-led; however, VAIC-value on the GVC-led and DPVC-led are similar, both being higher than FVC-led ones. This result shows difference with previous research hypothesizes, so further analysis needs to be done.

4.2. Correlation Analysis. Table 4 shows the correlation matrix for main variables of study; based on it, it is possible to see the following: (1) there is significant positive correlation between the ROA and the set of IC-related variables (HCE, SCE, ICE, RCE, and VAIC); however, no significant correlation is seen between the ROA and Lead_type or VctypeHeter. (2) Significant positive correlation was found between VAIC and HCE, SCE, ICE, and RCE, as well as between VAIC and Lead_type; although the correlation between VAIC and VctypeHeter is not significant, there is negative correlation between HCE and VctypeHeter (-0.099).
It is also relevant to mention that (3) significant positive correlation appeared between Lead_type, VctypeHeter; although the correlation between these two variables and ROA is not significant, negative significant correlation is found between these variables and some components of IC (HCE and Lead_type was $\left.0.084^{* *}\right)$. While there is significant positive correlation between components of IC and ROA, further relationship validation will be needed.

\subsection{Empirical Result Analysis}

4.3.1. Relationship of IC and Firm Performance. Table 5 shows that IC, HCE, SCE, ICE, and RCE all have a significantly positive impact on the portfolio firm performance, consistent with $\mathrm{H} 1$, since the $t$ values of regression coefficient for VAIC, HCE, SCE, ICE, and RCE are 12.61, 17.52, 17.87, 9.11, and 8.72 , respectively, with significance at $1 \%$ level. Moreover, the effects of human capital (2.269) and structural capital (2.211) on PFP are significantly higher than innovation $(0.312)$ and relationship capital (0.339). This finding is consistent with the first proposed argument that IC is composed of human capital and structural capital [15] and indicates that VCS can improve firm performance by providing valueadded services such as human capital, organizational management operations, and social relationship resources.

4.3.2. Role of VCS Leader Background between Intellectual Capital and Firm Performance. Based on the results shown in Table 6, regression coefficient of VAIC in group $1(0.647)$ is higher than in group $2(0.283)$ and group $3(0.227)$, meaning that compared with DPVC-led or GVC-led backed syndication firms, IC has a greater impact on performance of FVC-led firms supporting H2. As shown in Table 7, SUR estimation group analysis ( 1 vs 2,1 vs 3 ) showed that the 
TABLE 3: Descriptive statistical analysis of the main study variables.

\begin{tabular}{|c|c|c|c|c|c|c|c|}
\hline & Type & Variable & Sample & Mean & SE & Min & Max \\
\hline \multirow{18}{*}{ VCS leader background } & \multirow{6}{*}{ Backed by FVC-led syndication } & ROA & 64 & 5.919 & 3.501 & 0.1 & 14.843 \\
\hline & & HCE & 64 & 1.050 & 0.724 & 0.211 & 3.243 \\
\hline & & SCE & 64 & 1.426 & 0.757 & 0.402 & 3.893 \\
\hline & & ICE & 64 & 2.758 & 1.587 & 0.579 & 7.441 \\
\hline & & RCE & 64 & 2.201 & 1.901 & 0.212 & 7.868 \\
\hline & & VAIC & 64 & 7.435 & 3.530 & 1.878 & 15.186 \\
\hline & \multirow{6}{*}{ Backed by DPVC-led syndication } & $\mathrm{ROA}$ & 425 & 6.323 & 3.419 & -1.881 & 15.572 \\
\hline & & HCE & 425 & 1.440 & 0.728 & 0.231 & 3.478 \\
\hline & & SCE & 425 & 1.727 & 0.822 & 0.259 & 4.549 \\
\hline & & ICE & 425 & 4.524 & 3.379 & 0.543 & 19.873 \\
\hline & & RCE & 425 & 3.427 & 2.633 & 0.213 & 13.931 \\
\hline & & VAIC & 425 & 11.117 & 5.528 & 1.666 & 36.034 \\
\hline & \multirow{6}{*}{ Backed by GVC-led syndication } & ROA & 86 & 5.483 & 3.128 & -1.772 & 14.749 \\
\hline & & HCE & 86 & 1.346 & 0.717 & 0.328 & 3.298 \\
\hline & & SCE & 86 & 1.800 & 0.899 & 0.332 & 4.367 \\
\hline & & ICE & 86 & 4.589 & 3.267 & 1.158 & 16.674 \\
\hline & & RCE & 86 & 3.482 & 2.576 & 0.497 & 11.975 \\
\hline & & VAIC & 86 & 11.218 & 4.896 & 3.201 & 23.82 \\
\hline \multirow{12}{*}{ VCS cooperation model } & \multirow{6}{*}{ Backed by pure syndication } & $\mathrm{ROA}$ & 380 & 6.279 & 3.568 & -1.881 & 15.572 \\
\hline & & HCE & 380 & 1.425 & 0.755 & 0.211 & 3.478 \\
\hline & & SCE & 380 & 1.738 & 0.824 & 0.259 & 4.549 \\
\hline & & ICE & 380 & 4.388 & 3.188 & 0.543 & 19.873 \\
\hline & & RCE & 380 & 3.371 & 2.601 & 0.236 & 13.931 \\
\hline & & VAIC & 380 & 10.923 & 5.466 & 1.666 & 36.034 \\
\hline & \multirow{6}{*}{ Backed by mixed syndication } & $\mathrm{ROA}$ & 195 & 5.907 & 3.022 & 0.1 & 14.843 \\
\hline & & HCE & 195 & 1.300 & 0.688 & 0.252 & 3.243 \\
\hline & & SCE & 195 & 1.638 & 0.845 & 0.332 & 4.367 \\
\hline & & ICE & 195 & 4.236 & 3.392 & 0.579 & 19.595 \\
\hline & & RCE & 195 & 3.157 & 2.536 & 0.212 & 13.71 \\
\hline & & VAIC & 195 & 10.332 & 5.171 & 2.704 & 29.73 \\
\hline
\end{tabular}

TABLE 4: Correlation matrix for main study variables.

\begin{tabular}{|c|c|c|c|c|c|c|c|c|}
\hline Variables & ROA & HCE & SCE & ICE & RCE & VAIC & Lead_type & Vctype Heter \\
\hline ROA & 1.000 & & & & & & & \\
\hline $\mathrm{HCE}$ & $0.425^{* * *}$ & 1.000 & & & & & & \\
\hline SCE & $0.446^{* * *}$ & $0.587^{* * *}$ & 1.000 & & & & & \\
\hline ICE & $0.208^{* * *}$ & $0.301^{* * *}$ & $0.427^{* * *}$ & 1.000 & & & & \\
\hline RCE & $0.243^{* * *}$ & $0.328^{* * *}$ & $0.306^{* * *}$ & $0.198^{* * *}$ & 1.000 & & & \\
\hline VAIC & $0.370^{* * *}$ & $0.568^{* * *}$ & $0.641^{* * *}$ & $0.809^{* * *}$ & $0.692^{* * *}$ & 1.000 & & \\
\hline Lead_type & -0.043 & $0.084^{* *}$ & $0.107^{* *}$ & $0.129^{* * *}$ & $0.114^{* * *}$ & $0.161^{* * *}$ & 1.000 & \\
\hline VctypeHeter & 0.015 & $-0.099^{* *}$ & 0.015 & 0.037 & -0.062 & -0.021 & $0.112^{* *}$ & 1.000 \\
\hline
\end{tabular}

Note: ${ }^{* * *}$ significance at $1 \%$ level; ${ }^{* *}$ significance at $5 \%$ level; ${ }^{*}$ significance at $10 \%$ level.

coefficient difference of VAIC was all significant at $1 \%$; in the case of 2 vs 3 , there was no significant difference on VAIC, indicating no significant difference in the impact of IC on firm performance between firms backed by DPVC-led or GVC-led syndication. This is result is similar to that in [34] and in line with those of [92].

From the perspective of the components of IC, this study found no significant differences in the impact of human capital and structural capital on firm performance among firms invested by FVC-led, DPVC-led, or GVC-led syndication. As seen in Table 7, the SUR group test (1 vs 2, 1 vs 3, and 2 vs 3 ) showed no significant difference on coefficients of HCE and
SCE; however, there is significant difference in the impact of innovation capital on firm performance among them; from the coefficients of ICE in Table 6 and result of ICE's SUR-test in Table 7 , it can be seen that the impact of innovation capital on firm performance is higher in firms on FVC-led syndication than in the ones backed by DPVC-led or GVC-led. Additionally, the relationship capital of firms backed by GVC-led syndication has no significant impact on performance, but firms backed by FVC-led or DPVC-led syndication can effectively use their relationship capital to foster performance. As seen from the empirical test for groups, regression coefficients of RCE are significant except for group 3 (Table 6). 
TABLE 5: Influence of IC and its constituent elements on firm performance.

\begin{tabular}{|c|c|c|c|c|c|}
\hline IV & & & ROA & & \\
\hline VAIC & $0.283(8.69)^{* * *}$ & & & & \\
\hline HCE & & $2.269^{* * *}(11.98)$ & & & \\
\hline SCE & & & $2.211^{* * *}(12.23)$ & & \\
\hline ICE & & & & $0.312^{* * *}(5.62)$ & \\
\hline RCE & & & & & $0.339^{* * *}(6.17)$ \\
\hline Scale & $-0.444^{*}(-2.55)$ & $-0.377^{*}(-2.42)$ & $-0.899^{* * *}(-5.50)$ & $0.331^{* * *}(9.11)$ & $0.0688(0.38)$ \\
\hline Debt & $-0.051^{* * *}(-6.07)$ & $-0.043^{* * *}(-5.68)$ & $-0.038^{* * *}(-4.99)$ & $-0.055^{* * *}(-6.08)$ & $-0.056^{* * *}(-6.16)$ \\
\hline PPE & $-9.545^{* * *}(-8.45)$ & $-6.815^{* * *}(-6.84)$ & $-9.977^{* * *}(-9.64)$ & $-8.167^{* * *}(-6.89)$ & $-8.735^{* * *}(-7.21)$ \\
\hline $\mathrm{BN}$ & $-0.135(-1.53)$ & $-0.134(-1.67)$ & $-0.095(-1.18)$ & $-0.028(-0.31)$ & $-0.110(-1.16)$ \\
\hline TAT & $6.133^{* * *}(10.99)$ & $6.602^{* * *}(12.97)$ & $4.318^{* * *}(8.19)$ & $5.647^{* * *}(9.48)$ & $6.063^{* * *}(10.11)$ \\
\hline Constant & $14.75^{* * *}(3.97)$ & $11.22^{* * *}(3.38)$ & $23.35^{* * *}(6.70)$ & $7.126(1.83)$ & $4.716(1.21)$ \\
\hline Observations & 575 & 575 & 575 & 575 & 575 \\
\hline$R$-squared & 0.3060 & 0.4023 & 0.4035 & 0.2274 & 0.2218 \\
\hline Mean VIF & 1.10 & 1.09 & 1.13 & 1.10 & 1.09 \\
\hline
\end{tabular}

Note: $t$ statistics in parentheses. ${ }^{* * *}$ Significance at $1 \%$ level; ${ }^{* *}$ significance at $5 \%$ level; ${ }^{*}$ significance at $10 \%$ level.

TABLE 6: Test results of VCS leading firm background heterogeneity.

\begin{tabular}{|c|c|c|c|c|c|c|}
\hline Type & IV & & & ROA & & \\
\hline \multirow{9}{*}{ FVC-led syndication (group 1) } & VAIC & $0.724^{* * *}(4.20)$ & & & & \\
\hline & HCE & & $3.423^{*}(2.28)$ & & & \\
\hline & SCE & & & $2.828^{* * *}(4.22)$ & & \\
\hline & ICE & & & \multicolumn{3}{|c|}{$1.966^{* * *}(5.05)$} \\
\hline & RCE & & & & & $0.706^{* *}(2.23)$ \\
\hline & Control & $\mathrm{Y}$ & $\mathrm{Y}$ & $\mathrm{Y}$ & Y & $\mathrm{Y}$ \\
\hline & $R^{2}$ & 0.7207 & 0.570 & 0.721 & 0.771 & 0.502 \\
\hline & Observations & 64 & 64 & 64 & 64 & 64 \\
\hline & Mean VIF & 1.95 & 2.59 & 1.91 & 2.12 & 1.84 \\
\hline \multirow{9}{*}{ DPVC-led syndication (group 2) } & VAIC & $0.283^{* * *}(9.94)$ & & & & \\
\hline & HCE & & $2.146^{* * *}(9.95)$ & & & \\
\hline & SCE & & & $1.798^{* * *}(8.73)$ & & \\
\hline & ICE & & & \multicolumn{3}{|c|}{$0.308^{* * *}(5.67)$} \\
\hline & RCE & & & & & $0.397^{* * *}(6.3)$ \\
\hline & Control & $\mathrm{Y}$ & $\mathrm{Y}$ & $\mathrm{Y}$ & $\mathrm{Y}$ & $\mathrm{Y}$ \\
\hline & $R^{2}$ & 0.408 & 0.382 & 0.344 & 0.213 & 0.271 \\
\hline & Observations & 425 & 425 & 425 & 425 & 425 \\
\hline & Mean VIF & 1.11 & 1.11 & 1.15 & 1.11 & 1.10 \\
\hline \multirow{9}{*}{ GVC-led syndication (group 3) } & VAIC & $0.227^{* * *}(3.66)$ & & & & \\
\hline & $\mathrm{HCE}$ & & $2.129^{* * *}(4.24)$ & & & \\
\hline & SCE & & & $2.529^{* * *}(5.65)$ & & \\
\hline & ICE & & & \multicolumn{3}{|c|}{$0.255^{* * *}(2.71)$} \\
\hline & RCE & & & & & $0.048(0.31)$ \\
\hline & Control & $\mathrm{Y}$ & $\mathrm{Y}$ & $\mathrm{Y}$ & $\mathrm{Y}$ & $\mathrm{Y}$ \\
\hline & $R^{2}$ & 0.530 & 0.513 & 0.599 & 0.486 & 0.345 \\
\hline & Observations & 86 & 86 & 86 & 86 & 86 \\
\hline & Mean VIF & 1.41 & 1.36 & 1.44 & 1.60 & 1.39 \\
\hline
\end{tabular}

Note: $t$ statistics in parentheses. ${ }^{* * *}$ Significance at $1 \%$ level; ${ }^{* *}$ significance at $5 \%$ level; ${ }^{*}$ significance at $10 \%$ level.

4.3.3. Moderating Effect of VCS Member Heterogeneity. As shown in Table 8, the regression coefficient of the interaction between IC and heterogeneity type of VCS members is -0.259 significant at $5 \%$ level, implying that VCS member heterogeneity has significant negative moderating effect on the impact of IC on firm performance, indicating that stronger heterogeneity on VCS member background may reduce the positive impact of IC on firm performance, consistent with $\mathrm{H} 3 \mathrm{~b}$.
From the perspective of IC components, regression coefficient of the interaction terms corresponding to relational capital is -0.531 significant at $5 \%$ level, in other words, stronger VCS member heterogeneity can also reduce the positive impact of relational capital on firm performance. However, the regression coefficient for the interaction terms corresponding to human capital (-0.665), structural capital (-0.602), and innovation capital $(-0.382)$ is not significant, suggesting that more background does not imply better results within the VCS. 
TABle 7: SUR-group test (1 vs 2, 1 vs 3, and 2 vs 3 ) coefficient difference.

\begin{tabular}{|c|c|c|c|c|c|c|}
\hline \multirow[t]{2}{*}{ Main variable } & \multicolumn{2}{|c|}{$\begin{array}{l}\text { "Foreign" and "private" } \\
\text { (group } 1 \text { vs } 2 \text { ) }\end{array}$} & \multicolumn{2}{|c|}{$\begin{array}{c}\text { "Foreign" and } \\
\text { "government" (group } 1 \text { vs } \\
3 \text { ) }\end{array}$} & \multicolumn{2}{|c|}{$\begin{array}{c}\text { "Private" and } \\
\text { "government" (group } 2 \text { vs } \\
3 \text { ) }\end{array}$} \\
\hline & Chi2 & $p$-value & Chi2 & $p$-value & Chi2 & $p$-value \\
\hline VAIC & 8.50 & $0.004^{* * *}$ & 9.09 & $0.003^{* * *}$ & 0.44 & 0.507 \\
\hline HCE & 0.79 & 0.375 & 0.78 & 0.378 & 0.01 & 0.969 \\
\hline SCE & 2.20 & 0.138 & 0.15 & 0.699 & 2.65 & 0.103 \\
\hline ICE & 49.68 & $0.001^{* * *}$ & 31.81 & $0.001^{* * *}$ & 0.16 & 0.690 \\
\hline RCE & 1.24 & 0.266 & 4.52 & $0.033^{* *}$ & 4.33 & $0.037^{* *}$ \\
\hline
\end{tabular}

Note: ${ }^{* * *}$ Significance at $1 \%$ level; ${ }^{* *}$ significance at $5 \%$ level; ${ }^{*}$ significance at $10 \%$ level.

TABLE 8: Moderating effect of VCS member heterogeneity.

\begin{tabular}{|c|c|c|c|c|c|}
\hline IV & & & $\mathrm{ROA}$ & & \\
\hline IC/elements & VAIC $0.353^{* * *}(8.95)$ & HCE $2.612^{* * *}(10.01)$ & SCE $2.350^{* * *}(9.81)$ & ICE $0.435^{* * *}(5.13)$ & RCE $0.417^{* * *}(5.35)$ \\
\hline VCtypeHeter & $3.282^{* *}(2.74)$ & $2.609^{*}(2.37)$ & $1.632(1.53)$ & $1.824(1.86)$ & $2.431^{* *}(2.66)$ \\
\hline VAIC *VCtypeHeter & $-0.259^{* *}(-2.94)$ & & & & \\
\hline HCE $*$ VCtypeHeter & & $-0.665(-0.89)$ & & & \\
\hline SCE *VCtypeHeter & & & $-0.602(-1.04)$ & & \\
\hline ICE $*$ VCtypeHeter & & & & $-0.382(-1.90)$ & \\
\hline RCE $*$ VCtypeHeter & & & & & $-0.531^{* *}(-2.49)$ \\
\hline Scale & $-0.512(-1.88)$ & $-0.243(-0.94)$ & $-0.960^{* * *}(-3.59)$ & $-0.350(-1.18)$ & $-0.240(-0.81)$ \\
\hline Debt & $-0.063^{* * *}(-5.20)$ & $-0.06^{* * *}(-5.04)$ & $-0.043^{* * *}(-3.68)$ & $-0.06^{* * *}(-4.74)$ & $-0.059^{* * *}(-4.40)$ \\
\hline PPE & $-7.081^{* * *}(-4.25)$ & $-4.296^{* *}(-2.70)$ & $-7.740 * * *(-4.87)$ & $-7.19^{* * *}(-3.94)$ & $-5.455^{* *}(-2.99)$ \\
\hline $\mathrm{BN}$ & $-0.144(-1.19)$ & $-0.254^{*}(-2.16)$ & $-0.100(-0.87)$ & $0.005(0.04)$ & $-0.106(-0.79)$ \\
\hline TAT & $6.927^{* * *}(8.08)$ & $7.598^{* * *}(9.25)$ & $5.028^{* * *}(5.96)$ & $7.611^{* * *}(8.09)$ & $6.805^{* * *}(7.21)$ \\
\hline Constant & $14.20^{*}(2.46)$ & $8.103(1.48)$ & $23.80^{* * *}(4.21)$ & $11.22(1.79)$ & $9.941(1.58)$ \\
\hline$R^{2}$ & 0.397 & 0.444 & 0.448 & 0.280 & 0.267 \\
\hline Observations & 575 & 575 & 575 & 575 & 575 \\
\hline Mean VIF & 2.42 & 2.18 & 2.24 & 1.96 & 1.63 \\
\hline
\end{tabular}

Note: $t$ statistics in parentheses. ${ }^{* * *}$ Significance at $1 \%$ level; ${ }^{* *}$ significance at $5 \%$ level; ${ }^{*}$ significance at $10 \%$ level.

\subsubsection{Endogeneity Problems and Robustness Check}

(1) Endogeneity Problems. An increase of intellectual capital contributes to firm performance; nevertheless, considering that firms with higher performance may also attract intellectual capital improvement like better human resources, there may be reverse causation. Additionally, although multiple control variables have been selected in this research, there may be other endogenous problems such as missing variables. For these reasons, this exercise used the generalized method of moments (GMMs) to reduce endogeneity problems and control unobservable factors for the causality model. Following [46] and [47], the average IC value of the sample firm's industry was used as its own instrumental variable, which represents on average the impact of industry IC on firm performance. Generally, firms in the same industry learn and communicate with each other, influencing their IC and its components, but without directly affecting the firm's value-added activities.

The traditional Hausman test were used to carry out the endogeneity test on the main explanatory variables, showing that prob $>$ chi $2=0.0443$; the DWH test with robust heteroscedasticity showed Durbin $(p=0.0433)$ and $\mathrm{Wu}$ Hausman $(p=0.0443)$. These results prove the existence of endogenous problems and the applicability of the GMM method in this empirical exercise.

Test results of instrument variables showed that (1) Anderson canon corr: LM statistic was 23.556, with a $p$ value of 0.000 , strongly rejecting the under identification null hypothesis, indicating that the instrument variable is reasonable. (2) Cragg-Donald Wald $F$ statistic was 24.115, higher than the corresponding critical value of 16.38, rejecting the original hypothesis of "weak identification." Based on the above instrument variable tests and instrument variable method regression results, the results of this study appeared to be stable.

First-stage regression showed that all the coefficient of instrumental variable showed higher significance ( $p$ value $=0.0001$ ), and second-stage regression was also consistent to the conclusion, as shown in Table 9.

(2) Robustness Check. As shown in Tables 5-9, the value of mean VIF stayed between 1.59 and 2.09, meaning the absence of multicollinearity problems. For the moderate effect model, ROE was used instead of ROA to test moderating effect models' robustness of our results. As shown in Tables 10-12, the empirical results were materially consistent 
TABLE 9: Instrumental variables (GMM) regression.

\begin{tabular}{|c|c|c|c|c|c|}
\hline IV & & & $\mathrm{ROA}$ & & \\
\hline VAIC & $0.362^{* * *}(3.46)$ & & & & \\
\hline HCE & & $2.703^{* * *}(3.90)$ & & & \\
\hline SCE & & & $2.877^{* * *}(4.72)$ & & \\
\hline ICE & & & & $0.855^{* *}(2.81)$ & \\
\hline RCE & & & & & $0.675^{*}(2.25)$ \\
\hline Scale & $-0.918^{* *}(-2.68)$ & $-0.442^{*}(-2.02)$ & $-1.191^{* * *}(-4.20)$ & $-0.383(-1.48)$ & $0.0504(0.25)$ \\
\hline Debt & $-0.0491^{* * *}(-5.63)$ & $-0.0428^{* * *}(-5.51)$ & $-0.0348^{* * *}(-4.39)$ & $-0.060^{* * *}(-5.88)$ & $-0.063^{* * *}(-5.63)$ \\
\hline PPE & $-11.69^{* * *}(-6.56)$ & $-6.952^{* * *}(-6.75)$ & $-11.18^{* * *}(-7.24)$ & $-10.33^{* * *}(-5.99)$ & $-10.26^{* * *}(-5.53)$ \\
\hline $\mathrm{BN}$ & $-0.252^{*}(-2.24)$ & $-0.156(-1.74)$ & $-0.137(-1.53)$ & $-0.115(-1.01)$ & $-0.204(-1.60)$ \\
\hline TAT & $6.432^{* * *}(9.98)$ & $6.684^{* * *}(11.40)$ & $3.891^{* * *}(5.94)$ & $5.611^{* * *}(8.27)$ & $6.446^{* * *}(8.76)$ \\
\hline Constant & $24.03^{* * *}(3.49)$ & $12.34^{* *}(2.89)$ & $28.96^{* * *}(5.05)$ & $12.53^{*}(2.42)$ & $5.013(1.18)$ \\
\hline Observations & 575 & 575 & 575 & 575 & 575 \\
\hline$R$-squared & 0.189 & 0.398 & 0.370 & 0.011 & 0.151 \\
\hline
\end{tabular}

Note: $t$ statistics in parentheses. ${ }^{* * *}$ Significance at $1 \%$ level; ${ }^{* *}$ significance at $5 \%$ level; ${ }^{*}$ significance at $10 \%$ level.

TABLE 10: Robustness check results of different VCS leading backgrounds.

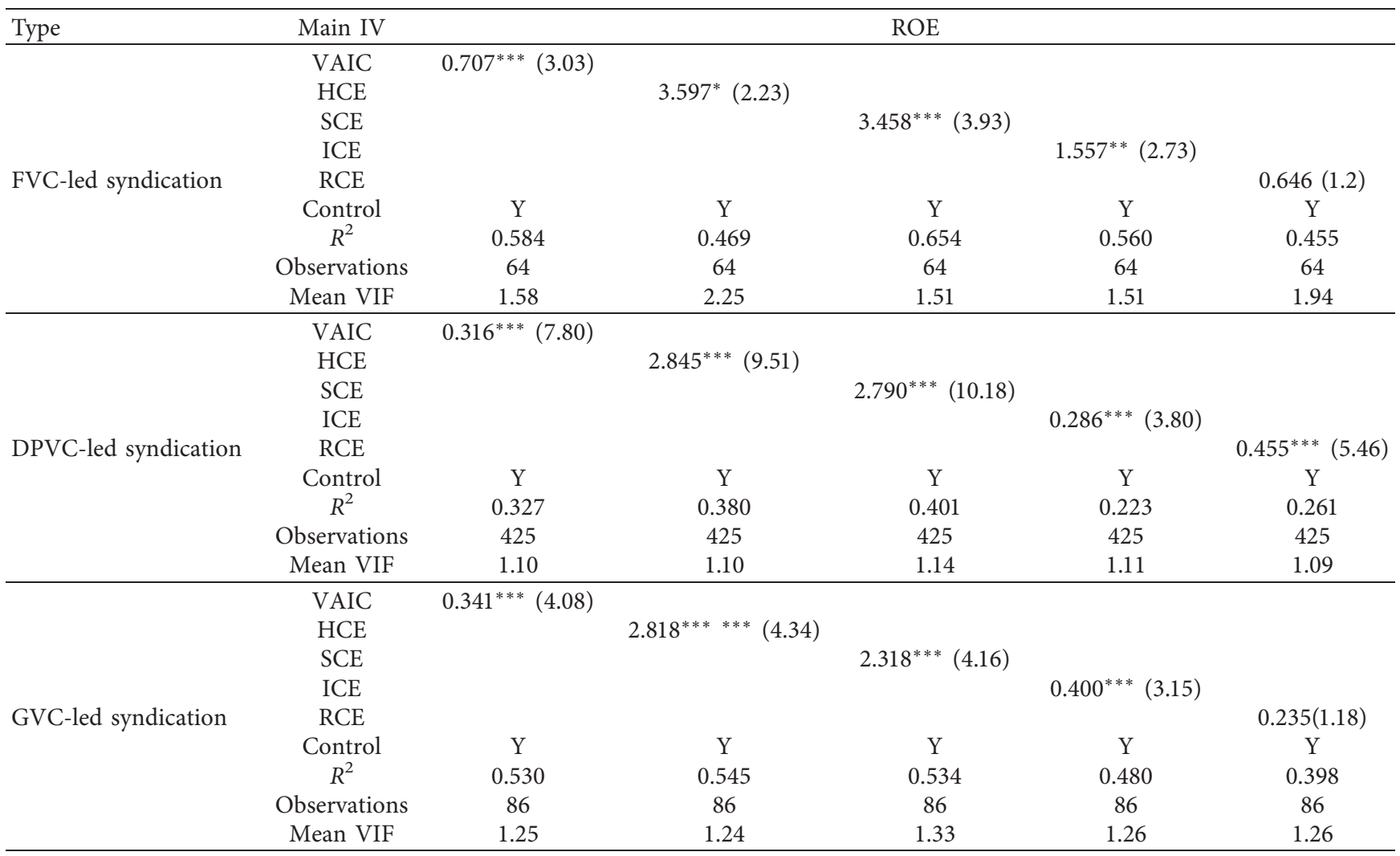

Note: $t$ statistics in parentheses. ${ }^{* * *}$ Significance at $1 \%$ level; ${ }^{* *}$ significance at $5 \%$ level; ${ }^{*}$ significance at $10 \%$ level.

TABLE 11: Robustness check results of SUR-test of group (Types 1 vs 2, 1 vs 3, and 2 vs 3) coefficient difference.

\begin{tabular}{|c|c|c|c|c|c|c|}
\hline \multirow[t]{2}{*}{ Main variable } & \multicolumn{2}{|c|}{$\begin{array}{l}\text { "Foreign" and "private" } \\
\text { (type } 1 \text { vs } 2 \text { ) }\end{array}$} & \multicolumn{2}{|c|}{$\begin{array}{c}\text { "Foreign" and } \\
\text { "government" (type } 1 \text { vs } 3 \text { ) }\end{array}$} & \multicolumn{2}{|c|}{$\begin{array}{c}\text { "Private" and } \\
\text { "government" (type } 1 \text { vs } \\
2 \text { ) }\end{array}$} \\
\hline & Chi2 & $p$ value & Chi2 & $p$ value & Chi2 & $p$ value \\
\hline VAIC & 4.19 & $0.040^{* *}$ & 3.12 & $0.077^{*}$ & 0.05 & 0.820 \\
\hline $\mathrm{HCE}$ & 0.76 & 0.381 & 0.73 & 0.392 & 0.00 & 0.962 \\
\hline SCE & 0.49 & 0.481 & 1.15 & 0.284 & 0.56 & 0.452 \\
\hline ICE & 9.02 & $0.003^{* * *}$ & 6.89 & $0.008^{* * *}$ & 0.43 & 0.513 \\
\hline RCE & 0.41 & 0.521 & 1.44 & 0.229 & 1.12 & 0.290 \\
\hline
\end{tabular}

Note: $t$ statistics in parentheses. ${ }^{* * *}$ Significance at $1 \%$ level; ${ }^{* *}$ significance at $5 \%$ level; ${ }^{*}$ significance at $10 \%$ level. 
TABLE 12: Robustness check results of moderating effect of VCS member heterogeneity.

\begin{tabular}{|c|c|c|c|c|c|}
\hline IV & & & ROE & & \\
\hline \multirow[t]{2}{*}{ IC and its elements } & VAIC & HCE & SCE & ICE & RCE \\
\hline & $0.379^{* * *}(6.78)$ & $3.175^{* * *}(8.77)$ & $2.866^{* * *}(8.60)$ & $0.398^{* * *}(3.41)$ & $0.453^{* * *}(4.24)$ \\
\hline VCtypeHeter & $3.156(1.86)$ & $2.801(1.83)$ & $1.893(1.27)$ & $1.391(1.03)$ & $3.091^{*}(2.47)$ \\
\hline VAIC *VCtypeHeter & $-0.211 *(-2.03)$ & & & & \\
\hline HCE $*$ VCtypeHeter & & $-0.289(-0.28)$ & & & \\
\hline SCE $*$ VCtypeHeter & & & $-0.514(-0.64)$ & & \\
\hline ICE $*$ VCtypeHeter & & & & $-0.186(-0.67)$ & \\
\hline RCE $*$ VCtypeHeter & & & & & $-0.614^{*}(-2.10)$ \\
\hline Scale & $-0.266(-0.69)$ & $0.0251(0.07)$ & $-0.865^{*}(-2.33)$ & $-0.0672(-0.16)$ & $0.0489(0.12)$ \\
\hline Debt & $-0.056^{* *}(-3.23)$ & $-0.051^{* *}(-3.17)$ & $-0.032(-1.94)$ & $-0.055^{* *}(-2.97)$ & $-0.051^{* *}(-2.77)$ \\
\hline PPE & $-10.68^{* * *}(-4.53)$ & $-7.336^{* * *}(-3.33)$ & $-11.58^{* * *}(-5.24)$ & $-10.61^{* * *}(-4.22)$ & $-8.713^{* * *}(-3.49)$ \\
\hline $\mathrm{BN}$ & $-0.232(-1.36)$ & $-0.392 *(-2.40)$ & $-0.197(-1.23)$ & $-0.076(-0.42)$ & $-0.190(-1.03)$ \\
\hline TAT & $9.325^{* * *}(7.68)$ & $10.22^{* * *}(8.98)$ & $6.956^{* * *}(5.93)$ & $9.991^{* * *}(7.70)$ & $9.268^{* * *}(7.17)$ \\
\hline Constant & $9.137(1.12)$ & $2.186(0.29)$ & $21.65^{* *}(2.75)$ & $5.679(0.66)$ & $3.967(0.46)$ \\
\hline Observations & 575 & 575 & 575 & 575 & 575 \\
\hline$R^{2}$ & 0.321 & 0.401 & 0.400 & 0.231 & 0.234 \\
\hline Mean VIF & 2.52 & 2.27 & 2.36 & 1.96 & 1.64 \\
\hline
\end{tabular}

Note: $t$ statistics in parentheses. ${ }^{* * *}$ Significance at $1 \%$ level; ${ }^{* *}$ significance at $5 \%$ level; ${ }^{*}$ significance at $10 \%$ level.

with previous research, demonstrating the robustness of the conclusions of this study.

\section{Discussions and Conclusions}

This study was intended to investigate the positive effect of intellectual capital (IC) on Chinese portfolio firm performance (PFP) and examine the influence of VCS leading firm heterogeneity as well as the moderating impact of member heterogeneity on this relationship (IC and PFP) by assessing three aspects: (1) VCS leading firm background, (2) VCS cooperation model, and (3) VCS member heterogeneity. Our results suggested that higher intellectual capital may provide advantages for VCS backed firms, and these advantages vary according to the nature of the syndication (FVC-led, DPVC-led, or GVC-led). The positive impact of innovation capital on the performance of firms backed by FVC-led syndication is higher than firms backed by DPVCled or GVC-led syndication; the positive effect of relational capital on the performance between firms backed by DPVCled or FVC-led is similar, but in firms backed by GVC-led syndication, there is no significant effect. Additionally, in pure syndication backed firms, IC positive effect in PFP is stronger than that in mixed syndication backed firms; on member heterogeneity, it reduces the positive effect of IC on PFP.

This study contributes to managerial theory and practice in various ways:

(1) First, this study considered the multidimensional characteristics of intellectual capital in Chinese portfolio firms by introducing innovative capital into the modified VAIC model. Most of previous studies have considered IC as composed by human capital, structure capital, or relational capital $[30,62,79]$; in contrast, just few studies gave attention to other components such as innovation capital. So, this study provides comprehensive analysis on IC efficiency within Chinese portfolio firms.
(2) Second, this empirical exercise contributes to existent literature on the association between intellectual capital and firm performance as most studies have focused on IC and firm performance in the context of developed countries $[1,10,78]$ or specific industries in emerging economies [30, 40, 49, 82]. This study extended the field of study to the role of venture-capital syndication (VCS) background in the relationship of intellectual capital (IC) and VCS-backed firm performance, finding that the applied 4-component IC (human capital, structure capital, relational capital, and innovation capital) can effectively improve the performance of VCS-backed firms in China. This study presents a certain difference with [2] who found that relational capital has a negative effect on firm performance; nevertheless, this can be explained by the difference of samples that in this study represents VCS-backed and successfully conducted IPO firms in China; since VCSbacked firms have stronger competitive advantages compared to others $[23,29]$, these firms can efficiently use their relational capital to improve firm performance. This reminds us to carefully analyze the key elements of VC firm intellectual capital, especially in the context of emerging economies.

(3) Third, this study extends also the actual literature on cross-border VC syndicates; previous studies focused on the impact of cross-border VC syndicates on investment performance [34, 105] or portfolio companies [95, 106, 107]. This empirical exercise performed further analysis on the importance of VeCS leading VC firms in their portfolio, finding that, in FVC-led syndication backed firms, IC has stronger positive impact on firm performance than in GVC-led syndication or DPVC-led syndication backed firms, consistent with [34], also supporting [108], where venture capitalists seem to prefer crossborder partners over domestic ones. Moreover, this study found that the mentioned effect is specially 
evidenced in the impact of innovation capital on firm performance; the impact of human capital and structural capital on PFP showed no significant difference between firms backed by FVC-led, DPVCled syndication, or GVC-led syndication. However, whether FVC-led or FVC-led syndication backed firms, relational capital has significant positive impact on PFP but not in firms backed by FVC-led syndication. This may be explained by the Chinese GVC political connections and restrictions, making it unable to make full use of its social relationships to improve the firm performance $[61,86]$.

In empirical terms, this study contributes to the growing literature on social identity theory and intellectual capital of portfolio firms, by complementing the previous studies that usually used the resourcebased theory to emphasize the role of VCS in improving IC and PFP $[23,29,109]$. However, fewer studies have focused on the impact of VCS's shortcomings on their portfolio companies [50, 75]. Based on the social identity theory, this research revealed negative effect of mixed VCSs on their portfolio companies, such as increase of communication costs [50] and growth of decision-making cycle [32], attenuating the positive effect of IC on PFP for firms backed by mixed VCS in comparison with pure VCS backed firms. These results also explain why VC firms would prefer to choose partners with similarities for joint investment, consistent with [50].

(4) This study contributes to managerial practice as new ventures can be more aware of the influence of VCS on the value creation ability of their IC. By one side, they could make comprehensive use of resources and capital advantages of VCS, by developing the elements of IC, especially human capital and structure capital, because based on these results, these components have stronger impact on PFP compared with innovation capital and relational capital. By the other side, VC firms could also pay attention to the downside of VCS, especially in relation with mixed VCS, as they need to minimize potential addition on coordination costs and maximize internal organizational management effectiveness. Therefore, firms can effectively combine the management of IC with VCS to enhance sustainable growth capabilities, combine the available VCS resources, improve the construction of their own relational capital, as well as introduce advanced knowledge, technology, and talents to increase the performance.

For VC firms, on the one hand, they can be aware of the differential influence of the VCS leading VC on their portfolio firms; this study showed that, for Chinese VC firms, it is relevant to strengthen the international cooperation and communication, in order to develop advanced capital operation methods and management concepts from FVC to improve their investment effectiveness; on the other hand, special attention should be given to the negative impact heterogeneity when selecting syndicate partners; this study showed that pure syndication may be a better choice to improve their PFP.

This study has some limitations: (1) first, it was mainly focused the role of VCS background between IC and PFP, the impact of factors such as experience heterogeneity and regional heterogeneity of VCS members were not included in this study; however, these can be included in future studies. (2) Second, given the difference of institutions between countries (especially compared with other in emerging economies), sample data did not include other countries or regions; further studies may expand the geographical range to a comparative study with referents in Asia and North America would be meaningful.

In summary, this study investigated the positive effect of IC on Chinese PFP and the role of Venture-capital syndication (VCS) background in the relationship between IC and PFP based on a sample of 575 VCS-backed and listed firms in Mainland China during 2014-2018. By using Pooled OLS model to test hypotheses, using GMM to reduce endogenous problems and control unobservable factors, and using return on equity instead of ROA to test the robustness of the results, this study results suggested that (1) intellectual capital (human capital, structural capital, innovation capital, and relational capital) has a positive impact on VCS' portfolio firms in China; results also showed that (2) VCS leading firm heterogeneity influences the relationship between IC and PFP; compared with DPVC-led or GVC-led syndication, IC is more effective to develop performance on firms backed by FVC-led syndication, which also suggest that (3) heterogeneity within syndication is less conducive to the value creation of the intellectual capital of their portfolio firms.

These results showed that VCS-backed firms, the increase of intellectual capital (including human capital, structure capital, innovation capital, and relational capital) is conductive to increase of firm performance; the relationship between intellectual capital and performance of portfolio firms is influenced by the background of syndicate members. This study highlights the importance of intellectual capital and the background of different syndication members in the promotion of firm value. It also points out that the effective combination of intellectual capital and venture capital firms can provide important value-added function for VC firms and its related actors.

\section{Data Availability}

The data sets used for this empirical study are publicly available in https://www.pedata.cn/data/index.html [33] and https://www.wind.com.cn/NewSite/data.html [99].

\section{Conflicts of Interest}

The authors declare that there are no conflicts of interest regarding the publication of this paper. 


\section{Acknowledgments}

The finding was sponsored by the pre-research project of the Donghua University Humanities and Social Sciences Prosperity Plan (2018Z001).

\section{References}

[1] F. Sardo and Z. Serrasqueiro, "Intellectual capital, growth opportunities, and financial performance in European firms," Journal of Intellectual Capital, vol. 19, no. 4, pp. 747-767, 2018.

[2] J. Xu, Y. Shang, W. Yu, and F. Liu, "Intellectual capital, technological innovation and firm performance: evidence from China's manufacturing sector," Sustainability, vol. 11, no. 19, p. 5328, 2019.

[3] W. Zhu, X. Dai, Y. Tian, X. Hu, and Z. Chao, "How intellectual capital combination method can improve corporate performance in China's information technology industry," IEEE Access, vol. 8, pp. 4824-4837, 2020.

[4] H. Itami and T. Roehl, Mobilizing Invisible Assets. Bibliovault OAI Repository, The University of Chicago Press, Chicago, IL, USA, 1987.

[5] J. Nahapiet and S. Ghoshal, "Social capital, intellectual capital, and the organizational advantage," Academy of Management Review, vol. 23, no. 2, pp. 242-266, 1998.

[6] M. A. Youndt, M. Subramaniam, and S. A. Snell, "Intellectual capital profiles: an examination of investments and returns," Journal of Management Studies, vol. 41, no. 2, pp. 335-361, 2004.

[7] W. S. Chang and J. J. Hsieh, "Intellectual capital and value creation-is innovation capital a missing link?" International Journal of Business and Management, vol. 6, no. 2, pp. 3-12, 2011.

[8] D. Maditinos, D. Chatzoudes, C. Tsairidis, and G. Theriou, "The impact of intellectual capital on firms' market value and financial performance," Journal of Intellectual Capital, vol. 12, no. 1, pp. 132-151, 2011.

[9] C.-Y. Tseng and Y.-J. James Goo, "Intellectual capital and corporate value in an emerging economy: empirical study of Taiwanese manufacturers," $R$ and D Management, vol. 35, no. 2, pp. 187-201, 2005.

[10] A. E. Bayraktaroglu, F. Calisir, and M. Baskak, "Intellectual capital and firm performance: an extended VAIC model," Journal of Intellectual Capital, vol. 20, no. 3, pp. 406-425, 2019.

[11] W. Duan, W. Zhan, and D. Liu, "From rapid growth to highquality development-review and prospect of China's 40 years of reform and opening up," Academics, vol. 33, no. 4, pp. 35-51, 2018.

[12] W. Zhang, X. Zhang, X. Tian, and F. Sun, "Economic policy uncertainty nexus with corporate risk-taking: the role of state ownership and corruption expenditure," Pacific-Basin Finance Journal, vol. 65, Article ID 101496, 2021.

[13] B. Waseem, B. Loo-See, A. Adeel, and A. Riaz, "Impact of intellectual capital on innovation capability and organizational performance: an empirical investigation," Serbian Journal of Management, vol. 13, no. 2, p. 365, 2018.

[14] L. Wang, Intellectual Capital Is an Important Force in $\mathrm{Na}$ tional Development Strategy, National New Books, 2015.

[15] A. Pulic, "Measuring the performance of intellectual potential in the knowledge economy," in Proceddings of the Paper Presented at the The 2nd World Congress on the
Management of Intellectual Capital, McMaster University, London, UK, 1998.

[16] T. Stewart, Intellectual Capital: The New Wealth of Organizations, WHO, NY, USA, 1997.

[17] I. Ulum, I. Ghozali, and A. Purwanto, "Intellectual capital performance of Indonesian banking sector: a modified VAIC (M-VAIC) perspective," Asian Journal of Finance \& Accounting, vol. 6, no. 2, p. 103, 2014.

[18] W. Y. Wu and H. J. Tsai, "Impact of social capital and business operation mode on intellectual capital and knowledge management," International Journal of Technology Management, vol. 30, no. 1/2, pp. 147-171, 2005.

[19] N. Ma and W. Meng, "The synergy effect test on venture capital and intellectual capital at the perspective of joint venture capital," Forecast, vol. 2, no. 36, pp. 30-36, 2017.

[20] D. Maditinos, Z. Sevic, and C. Tsairidis, "Intellectual capital and business performance: an empirical study for the Greek listed companies," European Research Studies Journal, vol. 13, 2010.

[21] M. Buenechea-Elberdin, A. Kianto, and J. Sáenz, "Intellectual capital drivers of product and managerial innovation in high-tech and low-tech firms," R\&D Management, vol. 48, no. 3, pp. 290-307, 2018.

[22] A. Seleim and N. Bontis, "National intellectual capital and economic performance: empirical evidence from developing countries," Knowledge and Process Management, vol. 20, no. 3, pp. 131-140, 2013.

[23] J. A. Brander, R. Amit, and W. Antweiler, "Venture-capital syndication: improved venture selection vs. The value-added hypothesis," Journal of Economics Management Strategy, vol. 11, no. 3, pp. 423-452, 2002.

[24] D. De Clercq and H. J. Sapienza, "Effects of relational capital and commitment on venture capitalists' perception of portfolio company performance," Journal of Business Venturing, vol. 21, no. 3, pp. 326-347, 2006.

[25] M. Sevilir, "Human capital investment, new firm creation and venture capital," Journal of Financial Intermediation, vol. 19, no. 4, pp. 483-508, 2010.

[26] X. Tian, G. Kou, and W. Zhang, "Geographic distance, venture capital and technological performance: evidence from Chinese enterprises," Technological Forecasting and Social Change, vol. 158, Article ID 120155, 2020.

[27] L. Gu, J. Guo, and H. Wang, "Corporate social responsibility, financing constraints, and the financialization of enterprises," Journal of Financial Research, vol. 63, no. 2, pp. 109-127, 2020.

[28] G. Dushnitsky and M. J. Lenox, "When do incumbents learn from entrepreneurial ventures?" Research Policy, vol. 34, no. 5, pp. 615-639, 2005.

[29] X. Tian, "The role of venture capital syndication in value creation for entrepreneurial firms," Review of Finance, vol. 16, pp. 245-283, 2010.

[30] J. Xu and J. Li, "The impact of intellectual capital on SMEs' performance in China," Journal of Intellectual Capital, vol. 20, no. 4, pp. 488-509, 2019.

[31] A. Lockett and M. Wright, "The syndication of venture capital investments," Omega, vol. 29, no. 5, pp. 375-390, 2001.

[32] M. Wright and A. Lockett, "The structure and management of alliances: syndication in the venture capital industry," Journal of Management Studies, vol. 40, no. 8, pp. 2073-2102, 2003.

[33] Zero2IPO Group, Zero2IPO Research Database, Zero2IPO Group, Beijing, China, 2020. 
[34] W. Liu, J. Cheng, and J. Jing, "Venture capital syndication's lead VC traits, cooperation pattern, heterogeneity degree and investment performance: an empirical study of China's listed companie," Nankai Business Review, vol. 06, no. 16, pp. 136-148, 2013.

[35] M. Ferrary, "Syndication of venture capital investment: the art of resource pooling," Entrepreneurship Theory and Practice, vol. 34, no. 5, pp. 885-907, 2010.

[36] O. Sorenson and T. E. Stuart, "Syndication networks and the spatial distribution of venture capital investments," American Journal of Sociology, vol. 106, no. 6, pp. 1546-1588, 2001.

[37] W. Zhang, X. Tian, and A. Yu, "Is high-speed rail a catalyst for the fourth industrial revolution in China? Story of enhanced technology spillovers from venture capital," Technological Forecasting and Social Change, vol. 161, Article ID 120286, 2020.

[38] E. Kong, W. X. Wei, P. Swallow, and S. B. Thomson, "Beltand-Road Initiative: driving the need to understand intellectual capital in Chinese multinational enterprises," Thunderbird International Business Review, vol. 62, no. 3, pp. 279-290, 2020.

[39] Q. L. Kweh, W.-M. Lu, and W.-K. Wang, "Dynamic efficiency: intellectual capital in the Chinese non-life insurance firms," Journal of Knowledge Management, vol. 18, no. 5, pp. 937-951, 2014.

[40] M. Zhang, Y. Qi, Z. Wang, K. S. Pawar, and X. Zhao, "How does intellectual capital affect product innovation performance? Evidence from China and India," International Journal of Operations \& Production Management, vol. 38, no. 3, pp. 895-914, 2018.

[41] J. Chen, X. Zhao, and Y. Wang, "A new measurement of intellectual capital and its impact on innovation performance in an open innovation paradigm," International Journal of Technology Management, vol. 67, no. 1, pp. 1-25, 2015.

[42] R. Krusinskas and J. Bruneckiene, "Measurement of intellectual capital of Lithuanian cities by a composite index," Journal of Business Economics and Management, vol. 16, no. 3, pp. 529-541, 2015.

[43] L. Uziene, "Model of organization's intellectual capital measurement," Inzinerine Ekonomika-Engineering Economics, vol. 21, no. 2, pp. 151-159, 2010.

[44] A. Wall, "The measurement and management of intellectual capital in the public sector," Public Management Review, vol. 7, no. 2, pp. 289-303, 2005.

[45] L. Zhou, "Analysis of the development status of venture capital in China," Contemporary Economics, vol. 16, no. 2, pp. 24-28, 2015.

[46] N. Ma and X. Ji, "Venture capital reputation, intellectual capital and enterprise value," Science Research Management, vol. 9, no. 40, pp. 96-107, 2019.

[47] C. Wu, S. Wu, J. Cheng, and L. Wang, "The role of venture capital in the investment and financing behavior of listed companies: evidence from China," Economic Research Journal, vol. 47, no. 01, pp. 105-119+160, 2012.

[48] Z. Cai, H. F. Liu, Q. Huang, L. Liang, and X. L. Shen, "Relational capital and performance: assessing the mediating role of supply chain agility and the moderating role of environmental contexts," in Proceedings of the Annual Hawaii International Conference on System Sciences, R. H. Sprague, Ed., pp. 4229-4238pp. 4229-, Waikoloa, HI, USA, 2014.

[49] H. Mei and K. Wang, "The impact of intellectual capital on high-tech enterprise performance: applied study in China's second-board market," in Eleventh International Conference on Management Science and Engineering Management, J. Xu,
M. Gen, A. Hajiyev, and F. L. Cooke, Eds., pp. 1677-1687, Springer, Berlin, Germany, 2018.

[50] Q. Du, "Birds of a feather or celebrating differences? The formation and impact of venture capital syndication," SSRN Electronic Journal, vol. 39, pp. 1-14, 2009.

[51] P. H. Sullivan and H. Patrick, "Profiting from intellectual capital," Journal of Knowledge Management, vol. 3, no. 2, pp. 132-143, 1999.

[52] M. Crema and C. Verbano, "Managing intellectual capital in Italian manufacturing SMEs," Creativity and Innovation Management, vol. 25, no. 3, pp. 408-421, 2016.

[53] J. López Rodríguez and B. Serrano Orellana, "Human capital and export performance in the Spanish manufacturing firms," Baltic Journal of Management, vol. 15, no. 1, pp. 99-119, 2020.

[54] C.-A. Ooi, C.-W. Hooy, and A. P. Mat Som, "Diversity in human and social capital: empirical evidence from Asian tourism firms in corporate board composition," Tourism Management, vol. 48, pp. 139-153, 2015.

[55] M. Nourani, V. Chandran, Q. L. Kweh, and W.-M. Lu, "Measuring human, physical and structural capital efficiency performance of insurance companies," Social Indicators Research, vol. 137, no. 1, pp. 281-315, 2018.

[56] Y. C. Wan, C. H. Chen, and X. Deng, "Structural capital, supply chain collaboration and buyer performance improvement: a theoretical model," in Proceedings o the International Conference on Computer Science and Information Technology, Y. Hang, W. Desheng, and P. S. Sandhu, Eds., pp. 60-63pp. 60-, Chengdu, China, 2010.

[57] N. M. Nor and N. J. Nor, The Influence of Structural Capital and Knowledge Management on the Performance: The Case Study of Telekom Malaysia Headquarters, Universiti Teknologi MARA (UiTM), Shah Alam, Malaysia, 2008.

[58] L. Qian, P. Yang, and J. Xue, "Hindering or enabling structural social capital to enhance buyer performance? The role of relational social capital at two levels in China," Journal of Business-to-Business Marketing, vol. 25, no. 3, pp. 213-231, 2018.

[59] M. Cucculelli, V. Peruzzi, and A. Zazzaro, "Relational capital in lending relationships: evidence from European family firms," Small Business Economics, vol. 52, no. 1, pp. 277-301, 2019.

[60] M. Hosseini and M. S. Owlia, "Designing a model for measuring and analyzing the relational capital using factor analysis," Journal of Intellectual Capital, vol. 17, no. 4, pp. 734-757, 2016.

[61] Y. Yu and B. Huo, "The impact of relational capital on supplier quality integration and operational performance," Total Quality Management \& Business Excellence, vol. 30, no. 11-12, pp. 1282-1301, 2019.

[62] N. Bontis, W. Chua Chong Keow, and S. Richardson, "Intellectual capital and business performance in Malaysian industries," Journal of Intellectual Capital, vol. 1, no. 1, pp. 85-100, 2000.

[63] A. Rahim, R. Atan, and A. Kamaluddin, "Intellectual capital efficiency in Mpublic companies: a longitudinal study," in Proceedings of the International Conference on Intellectual Capital, Hong Kong, China, 2010.

[64] Z. N. Wang, "Empirical study of finance distress prediction based on pulic's intellectual capital model," Application of Statistics and Management, vol. 28, no. 2, pp. 309-317, 2009.

[65] J. Chen, Z. Zhu, and H. Yuan Xie, "Measuring intellectual capital: a new model and empirical study," Journal of Intellectual Capital, vol. 5, no. 1, pp. 195-212, 2004. 
[66] J. A. Nazari and I. M. Herremans, "Extended VAIC model: measuring intellectual capital components," Journal of Intellectual Capital, vol. 8, no. 4, pp. 595-609, 2007.

[67] D. B. Audretsch and A. N. Link, "Innovation capital," The Journal of Technology Transfer, vol. 43, no. 6, pp. 1760-1767, 2018.

[68] H. Lööf and A. Heshmati, "Knowledge capital and performance heterogeneity:," International Journal of Production Economics, vol. 76, no. 1, pp. 61-85, 2002.

[69] T. Bassetti, L. Dal Maso, G. Liberatore, and F. Mazzi, "A critical validation of the value added intellectual coefficient: use in empirical research and comparison with alternative measures of intellectual capital," Journal of Management and Governance, vol. 24, no. 4, p. 1115, 2019.

[70] S. Pirjo, S. Sten, and A. Samuli, "Value added intellectual coefficient (VAIC): a critical analysis," Journal of Intellectual Capital, vol. 12, no. 4, pp. 531-551, 2011.

[71] Y. V. Hochberg, A. Ljungqvist, and Y. Lu, "Whom you know matters: venture capital networks and investment performance," The Journal of Finance, vol. 62, no. 1, pp. 251-301, 2007.

[72] Y. Lu, Y. Zhang, R. Jia, and J. Li, "Venture capital syndication and corporate innovation," Journal of Financial Research, vol. 60, no. 6, pp. 159-175, 2017.

[73] J. Ren, "Venture capital syndication, intellectual capital and its impact on corporate value creation," Journal of Commercial Economics, vol. 11, pp. 184-185, 2016.

[74] P. Giot and A. Schwienbacher, "IPOs, trade sales and liquidations: modelling venture capital exits using survival analysis," Journal of Banking \& Finance, vol. 31, no. 3, pp. 679-702, 2007.

[75] Y. Zhang, "Gain or pain? New evidence on mixed syndication between governmental and private venture capital firms in China," Small Business Economics, vol. 51, no. 4, pp. 995-1031, 2018.

[76] H. Liu and T. Yan, "Intellectual capital, venture capital and efficiency of high-end equipment manufacturing enterprises-an empirical study based on DSBM method and Tobit model," Journal of Shanxi University of Finance and Economics, vol. 37, no. 05, pp. 63-72, 2015.

[77] N. Ma, T. Yan, and X. Ji, "Analysis on venture capital and intellectual capital synergetic condition," Chinese Journal of Management Science, vol. 23, no. 3, pp. 24-31, 2015.

[78] A. Riahi-Belkaoui, "Intellectual capital and firm performance of US multinational firms," Journal of Intellectual Capital, vol. 4, pp. 215-226, 2003.

[79] S. Ghosh and A. Mondal, "Indian software and pharmaceutical sector IC and financial performance," Journal of Intellectual Capital, vol. 10, no. 3, pp. 369-388, 2009.

[80] J. Li and F. Li, "An empirical analysis of corporate intellectual capital and corporate performance," Journal of Chongqing University, vol. 12, pp. 134-138, 2004.

[81] Y. Liu and X. Zhao, "The effectiveness study of intellectual capital in driving business value-creation-based on the comprehensive appraisal of intellectual capital," Journal of Central University of Finance \& Economics, vol. 33, no. 1, pp. 41-46+49, 2013

[82] J. Xu and B. Wang, "Intellectual capital performance of the textile industry in emerging markets: a comparison with China and South Korea," Sustainability, vol. 11, no. 8, p. 2354, 2019.

[83] T. E. Stuart, H. Hoang, and R. C. Hybels, "Interorganizational endorsements and the performance of entrepreneurial ventures," Administrative Science Quarterly, vol. 44, no. 2, pp. 315-349, 1999.

[84] H. Bruining, M. Wright, E. Verwaal, A. Lockett, and S. Manigart, "Firm size effects on venture capital syndication: the role of resources and transaction costs," 2006, https:// ssrn.com/abstract $=870128$.

[85] A. Lockett, "Structure and management of syndicated venture capital investments," The Journal of Private Equity, vol. 5, pp. 72-83, 2002.

[86] X. Zhang and L. Liao, "Venture capital background and firm IPO: market performance and internal mechanism," Economic Research Journal, vol. 46, no. 6, pp. 118-132, 2011.

[87] F. Bertoni and T. Tykvová, "Does governmental venture capital spur invention and innovation? Evidence from young European biotech companies," Research Policy, vol. 44, no. 4, pp. 925-935, 2015.

[88] J. Brander, E. Egan, and T. Hellmann, Government Sponsored versus Private Venture Capital: Canadian Evidence, National Bureau of Economic Research, Inc, NBER Working Papers, Cambridge, MA, USA, 2008.

[89] Y. Alperovych, G. Hübner, and F. Lobet, "How does governmental versus private venture capital backing affect a firm's efficiency? Evidence from Belgium," Journal of Business Venturing, vol. 30, no. 4, pp. 508-525, 2015.

[90] L. Bottazzi, M. Darin, and T. Hellmann, "Who are the active investors? «Evidence from venture capital," Journal of Financial Economics, vol. 89, no. 3, pp. 488-512, 2008.

[91] L. Grilli and S. Murtinu, "New technology-based firms in Europe: market penetration, public venture capital, and timing of investment," Industrial and Corporate Change, vol. 24, no. 5, pp. 1109-1148, 2015.

[92] X. Zhang and D. Yang, "Study on foreign venture capital entering into Chinese venture capital," Studies in Science of Science, vol. 24, pp. 74-78, 2006.

[93] E. J. Ko and A. McKelvie, "Signaling for more money: the roles of founders' human capital and investor prominence in resource acquisition across different stages of firm development," Journal of Business Venturing, vol. 33, no. 4, pp. 438-454, 2018.

[94] R. Cressy, A. Malipiero, and F. Munari, "Does VC fund diversification pay off? An empirical investigation of the effects of VC portfolio diversification on fund performance," International Entrepreneurship and Management Journal, vol. 10, no. 1, pp. 139-163, 2014.

[95] D. Cumming, A. Knill, and K. Syvrud, "Do international investors enhance private firm value? Evidence from venture capital," Journal of International Business Studies, vol. 47, no. 3, pp. 347-373, 2016.

[96] S. Park, J. A. Lipuma, and S. S. Park, "Concentrating too hard? Foreign and corporate venture capital involvement in syndicates," Journal of Small Business Management, vol. 57, no. 2, pp. 327-342, 2019.

[97] J. Cheng, "A literature review of the relationship between entrepreneurial team heterogeneity and entrepreneurial performance," Foreign Economics \& Management, vol. 10, no. 39, pp. 3-17, 2017, https://kns.cnki.net/kcms/detail/ detail.aspx? dbcode $=$ CJFD\&filename $=$ WGJG201710001\&dbname=CJFDLAST2017.

[98] B. Urban, "Social capital configurations for necessity-driven versus opportunity-driven entrepreneurs," South African Journal of Economic and Management Sciences, vol. 14, no. 4, pp. 407-421, 2011.

[99] M. Williams, "Being trusted: how team generational age diversity promotes and undermines trust in cross-boundary 
relationships," Journal of Organizational Behavior, vol. 37, no. 3, pp. 346-373, 2015.

[100] B. Clarysse, A. Bobelyn, and I. del Palacio Aguirre, "Learning from own and others' previous experience: the contribution of the venture capital firm to the likelihood of a portfolio company's trade sale," Small Business Economics, vol. 40, no. 3, pp. 575-590, 2013.

[101] ChinaVenture Investment Consulting Co, CVSource Database, ChinaVenture Investment Consulting Co, China, 2020, https://www.cvsource.com.cn.

[102] Wind, Wind Financial Database, 2020.

[103] H. Liu and H. Teng, "A study of the threshold effect of R\&D intensity on corporate value based on enterprise life cycle," Science Research Management, vol. 41, no. 1, pp. 193-201, 2020.

[104] Q. Luo and H. Luo, "The analysis of the "value-added" function of venture capital: based on the perspective of internet-based information disclosure," Nankai Business Review, vol. 01, no. 21, pp. 63-74, 2018.

[105] L. Wang and S. Wang, "Cross-border venture capital performance: evidence from China," Pacific-Basin Finance Journal, vol. 19, no. 1, pp. 71-97, 2011.

[106] Y. He, B. Li, Y. Tian, and L. Wang, "Does foreign venture capital provide more value-added services to initial public offering companies in China?" China \& World Economy, vol. 24, no. 2, pp. 90-106, 2016.

[107] H. Woo, "Foreign venture capital firms and internationalization of ventures," Multinational Business Review, vol. 28, no. 3 , p. $381,2020$.

[108] C. Plagmann and E. Lutz, "Beggars or choosers? Lead venture capitalists and the impact of reputation on syndicate partner selection in international settings," Journal of Banking \& Finance, vol. 100, pp. 359-378, 2019.

[109] T. Liu and S. Qu, "Joint venture capital's contribution to start-up Enterprises'Value creation," Forecast, vol. 2, no. 37, pp. 56-62, 2018. 